Haya: The Saudi Journal of Life Sciences

Abbreviated Key Title: Haya Saudi J Life Sci ISSN 2415-623X (Print) |ISSN 2415-6221 (Online) Scholars Middle East Publishers, Dubai, United Arab Emirates Journal homepage: https://saudijournals.com/sjls

Original Research Article

\title{
Nitrogen and Phosphorus Acquisition of Rattan Seeds Grown in Rizoboxes
} Lisa Indriani Bangkele ${ }^{1 *}$, Muhammad Basir-cyio ${ }^{2}$, Aiyen Tjoa ${ }^{2}$, Andi Tanra Tellu ${ }^{3}$

${ }^{1}$ Student of Agricultural Doctoral Programme, Tadulako University, Palu, Indonesia

${ }^{2}$ Faculty of Agriculture, Tadulako University, Palu, Indonesia

${ }^{3}$ Departement of Biology, Tadulako University, Palu, Indonesia

DOI: $10.36348 /$ sjls.2020.v05i03.001 $\quad$ | Received: 06.03.2020 | Accepted: 13.03.2020 | Published: 20.03.2020

*Corresponding author: Lisa Indriani Bangkele

Abstract

The type of fertilizer and fertilization techniques affect the biochemical of the rhizosphere. Different Nitrogen fertilizer inputs will have different effects in the process of releasing $\mathrm{N}$ ions, soil $\mathrm{pH}$, number of colonies and respiration activity of soil microorganisms, so that it will affect the acquisition of Nitrogen $(\mathrm{N})$ and Phosphorus (P). Meanwhile, different fertilization techniques will provide different stimulations to root growth, so that it will affect the acquisition of $\mathrm{N}$ and $\mathrm{P}$, as well as the production of rattan seedling biomass. This study used rizoboxes which were designed as a 2-factor factorial experiment. Factor I: N-Urea $\left(\left(\mathrm{NH}_{2}\right) 2 \mathrm{CO}\right)$ and N-ZA $\left(\left(\mathrm{NH}_{4}\right) 2 \mathrm{SO}_{4}\right)$, and factor II: Homogeny Fertilization and Localized Fertilization. The results showed that $\mathrm{N}-\mathrm{ZA}$ input decreased soil $\mathrm{pH}$, causing the highest number of microorganism colonies, but did not increase the respiration activity of microorganisms. N-Urea input also decreased soil $\mathrm{pH}$ and increased the number of microorganism colonies. However, both N-ZA and N-Urea showed no significant effects on $\mathrm{N}$ acquisition and production of rattan seedling biomass. Localized fertilization caused rooting to be concentrated in the fertilizing area, decreased $\mathrm{N}$ acquisition, otherwise increased $\mathrm{P}$ acquisition, but cannot increase rattan seedling biomass.

Keywords: Acquisition, biochemical, homogeneous Fertilization, localized fertilization rizosphere.

Copyright @ 2020: This is an open-access article distributed under the terms of the Creative Commons Attribution license which permits unrestricted use, distribution, and reproduction in any medium for non-commercial use (NonCommercial, or CC-BY-NC) provided the original author and source are credited.

\section{INTRODUCTION}

In general, plant growth is positively correlated with the provision of inputs (fertilizers, pesticides, including crop management), but the magnitude of the correlation is strongly influenced by both supporting and inhibiting factors, so it is specific to each plant. Knowledge of the effects of inputs on rhizosphere changes provides important scientific value for understanding plant growth. Provision of agricultural inputs has a major influence on the condition of the root area and root response. The influence of agricultural inputs such as fertilizers given to plants can be measured. The effect of the fertilizer differs depending on the type of fertilizer, growing media, types of plants, and also ecology. In research related to fertilizers, many have reported their effects on plant growth (morphology and physiology), both in the shoot and roots. As reported by[1] in T. caerulencens plants, $\mathrm{N}_{-} \mathrm{NO}_{3}{ }^{-}$increased higher shoot and root biomass compared to $\mathrm{N}_{-} \mathrm{NH}_{4}{ }^{+}$. However, this is different from the results of research by [2] in wheat plants that biomass and $\mathrm{N}$ acquisition were higher in $\mathrm{NH}_{4}^{+}$ applications than $\mathrm{NO}_{3}$.
Fertilization techniques, such as fertilizer mixed homogeneously, localized, buried or sown also affect the response of plants. Localized fertilizer application in several studies was reported to cause physiological stress in plants, but in some plants it can increase plant productivity better as a result of its physiological adaptation [3, 4]. Rattan is one of the economically important forest plants in Indonesia [5]. Indonesia is a major producer and supplier of rattan in the world. Most of Indonesia's rattan only relies on natural rattan sources that causes continued decline in the potential of Indonesian rattan production, so cultivation must be carried out. Rattan cultivation research is important to increase knowledge in rattan cultivation techniques [6]. This study was conducted to examine the biochemical changes of the rhizosphere due to fertilization affecting the acquisition of Nitrogen $(\mathrm{N})$ and Phosphorus (P) by rattan seedling roots, as well as their effect on the production of rattan seedling biomass. 


\section{MATERIALS AND METHODS}

\section{Location and Time}

Research of Rizobox was conducted from February 2017 to July 2017 at the Green House facility at Faculty of Agriculture, Tadulako University. Soil pH analysis was carried out at the Soil Laboratory and Laboratory of Agronomy, Tadulako University. Analysis of the number of microorganism colonies was carried out at Plant Protection Laboratory; $\mathrm{N}$ and $\mathrm{P}$ analysis was carried out at the Indonesian Institute of Sciences Laboratory, Tangerang.

\section{Research Design}

This study used a randomized block design (RBD) with 2 factors. The treatment was repeated 4 (four) times, so that it was obtained $3 \times 2 \times 4=24$ treatment units. To test the effect of treatment, the analysis of variance was performed. The results of the analysis that showed significant effects were followed by a further test of Least Significant Difference test (LSD) level of 0.05 .

Table-1: Research Design

\begin{tabular}{|c|l|l|l|}
\hline No & \multicolumn{1}{|c|}{ Factor II } & \multicolumn{2}{c|}{ Factor I } \\
\cline { 3 - 4 } & & \multicolumn{1}{|c|}{$(\mathrm{H})$} & \multicolumn{1}{|c|}{ ( ) } \\
\hline 1 & Control $(\mathrm{C})$ & $\mathrm{HC}$ & $\mathrm{LC}$ \\
\hline 2 & $\mathrm{~N} \mathrm{Urea} ; 100 \mathrm{~kg} \mathrm{~N} / \mathrm{Ha}+\mathrm{P}$ SP36;50 kg P/Ha (NU) & HNU & LNU \\
\hline 3 & $\mathrm{~N} \mathrm{ZA} ; 100 \mathrm{~kg} \mathrm{~N} / \mathrm{Ha}+\mathrm{P}$ SP36; $50 \mathrm{~kg} \mathrm{P} / \mathrm{Ha}(\mathrm{NZA})$ & $\mathrm{HNZA}$ & $\mathrm{LNZA}$ \\
\hline
\end{tabular}

Remarks : Homogeneous Fertilization (H), Localized Fertilization (L)

\section{MATERIALS AND EQUIPMENT}

Materials and equipment used were Rizoboxes made of acrilyc assembled with bolt and drill (tools for making rizoboks), black plastic, transparent plastic (OHP), electric scales, PH meter, cutter, filter, hands prayer; $500 \mathrm{~mL}$ measuring cup, $100 \mathrm{~mL}$ measuring cup, scaled pipette, ruler, meter, soil taken from the Sejahtera Village, Palolo Subdistrict with a $\mathrm{pH}$ of 5.6 ( $\mathrm{pH}$ Aquadest), inorganic Nitrogen (Urea), inorganic Nitrogen (Ammonium Sulfate or ZA), inorganic phosphorus (SP36), inorganic Potassium $(\mathrm{KCl})$, rattan seedlings of the Noko variety (Daemonorops sp.) of 8 weeks old seedlings, $\mathrm{HCl}, \mathrm{NaOH}, \mathrm{H}_{2} \mathrm{SO}_{4}, \mathrm{pH}$ buffer 4 , 7 and 9, Purple Bromochresole, tissue paper, and aquadest.

\section{Procedures of Rizoboks Research}

Rizoboxes were filled with soil up to $25 \mathrm{~cm}$ high so that the soil needed for each rizoboks was 1.20 $\mathrm{kg}$ of soil $\left(25 \mathrm{~cm} \mathrm{x} 16 \mathrm{~cm} \mathrm{x} 2.5 \mathrm{~cm} \mathrm{x} 1.20 \mathrm{~g} \mathrm{~cm}^{-3}\right)$. The soil was added to the rizoboxes with a soil density of $1.20 \mathrm{~g} \mathrm{~cm}^{-3}$. Healthy and uniform seeds were chosen to be transferred into the rizoboxes. Planting was performed at a uniform base of the stem. Rizoboxes were wrapped in thick black plastics and placed with a slope of $45^{\circ}$.

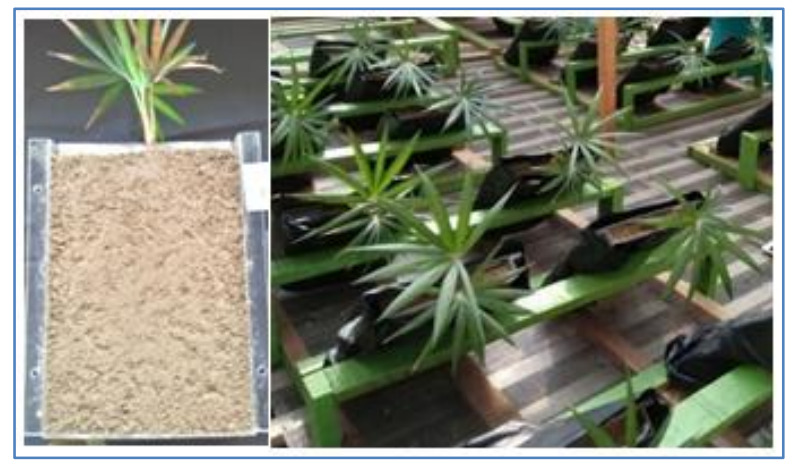

Fig-1: Rattan plants grown in Rizoboxes

\section{RESULTS AND DISSCUSSION Rhizosphere Biochemical Changes \\ Relationship $\rightarrow$ Correlation $\mathrm{R} 2=46.7 \%$}

However, treatment with localized fertilization shows a higher number of colonies of microorganisms compared to homogeneous fertilization.

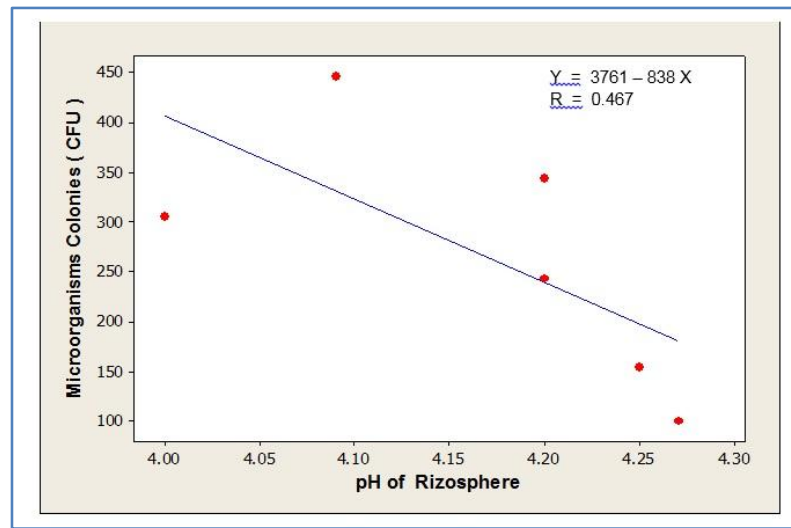

Fig-2: Regression between $\mathrm{pH}$ of the Rizosphere and Microorganisms Colonies (MO) (x100) CFU in Control, Homogeneous N-Urea, Homogeneous N-ZA, Localized N-Urea, Localized N-ZA treatments

Biochemical changes in the rhizosphere have an effect on the growth and development of microorganisms, while changes that cannot be tolerated can cause inhibition and even death of microorganisms. Very low pH can change the composition of dominant microorganisms in the rhizosphere and may even inhibit the development of bacteria related to the nitrogen cycle in the rhizosphere. In this study, the rhizosphere $\mathrm{pH}$ was around 4.0-4.4 so that it could inhibit the growth of nitrification or denitrification bacteria. 
Effects of N-Urea and N-ZA Homogenous and Localized Fertilizations on $\mathbf{N}$ and $\mathbf{P}$ Acquisition

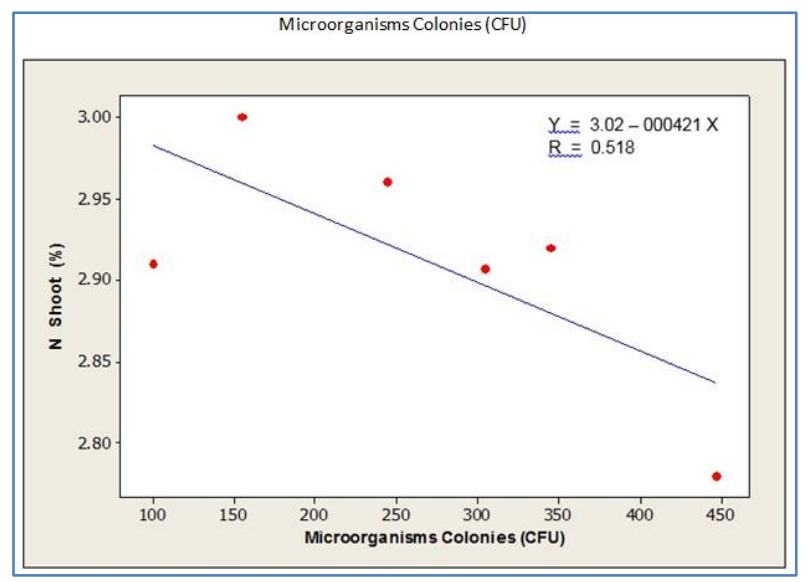

Fig-3: Concentration of $\mathrm{N}$ with Microorganisms Colonies (MO) (x100) CFU in Control, Homogeneous N-Urea, Homogeneous NZA, Localized N-Urea, Localized N-ZA treatments

Effects of Urea and ZA on Root Growth and Biochemical Changes of the Rizosphere. Urea $\left(\mathrm{CO}\left(\mathrm{NH}_{2}\right)_{2}\right)$ is a hygroscopic nitrogen fertilizer at $73 \%$ humidity. To be absorbed by plants, $\mathrm{N}$ in urea must be converted to ammonium $\left(\mathrm{NH}_{4}{ }^{+}\right)$with the help of the urease enzyme. Urea in the soil is very easily transformed into ammonia [7]. ZA fertilizer contains $24 \%$ sulfur (in the form of sulfate) and $21 \%$ nitrogen (in the form of ammonium). The $\mathrm{S}$ element is one of the main constituents of the cell nucleus and an important element in the formation of proteins [8].

Figure 3 show that the number of colonies of microorganisms has a fairly high relationship with the canopy N-concentration (51.8\%). In this study, colonies of microorganisms affected the concentration of $\mathrm{N}$ in the canopy.

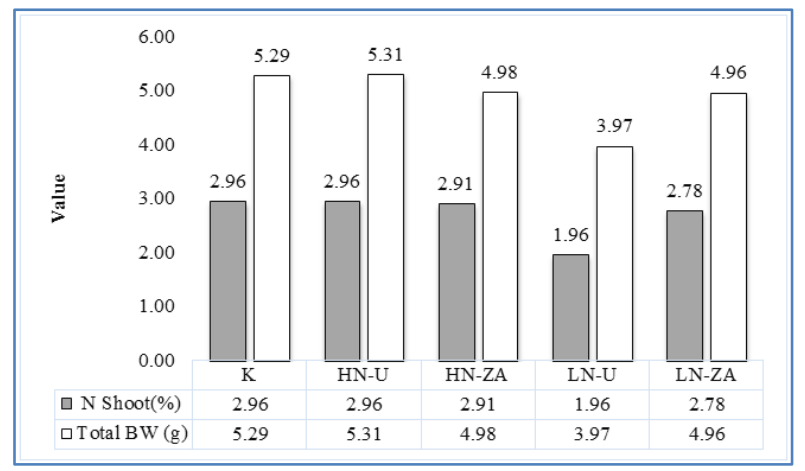

Fig-4: Concentration of N Canopy and Total Dry Biomass of Rattan Seedlings in Control, Homogeneous N-Urea,

Homogeneous N-ZA, Localized N-Urea, Localized N-ZA treatments

Shoot concentrations and biomass production of control treatments were higher (Figure 4). This shows that there were obstacles in the acquisition or biomass production in the treatment with $\mathrm{N}$-Urea and $\mathrm{N}-\mathrm{ZA}$ fertilizer inputs. This is in line with the research results by [9] that mentioned the addition of nitrogen can reduce the concentration of $\mathrm{N}, \mathrm{P}, \mathrm{K}$ and $\mathrm{Mn}$ in root tissue of bamboo plants (Pleioblastus amarus). However, the results of this study is in contrast with the results of some researchers reported that the administration of inorganic $\mathrm{N}$ plus protein (BSA) to Arabidopsis plants results in higher root dry weight, thicker roots, and longer hair roots [10].

Localized fertilization techniques cause the physiological stress of plant roots, change the architecture and morphology of rattan roots, and reduce the distribution or spread of roots in the soil thereby reducing the chance of acquisition of $\mathrm{N}$ and other nutrients. It also causes the production of rattan seedling biomass in localized fertilization to be lower than in homogeneous fertilization. In contrast to the acquisition of $\mathrm{N}$, the acquisition of $\mathrm{P}$ tends to be higher in localized fertilization techniques. Localization of $\mathrm{P}$ fertilizer will reduce fertilizer contact with soil, so that phosphate immobilization to become unavailable forms is lower. These results are in line with the research results by[2] and [11] that also obtained $\mathrm{P}$ fertilizer localization in Eucalyptus grandis plants showed higher $\mathrm{P}$ acquisition, also better $\mathrm{N}$ assimilation than homogeneous fertilization.

\section{Biochemical of the Rhosphere and the Nutrition Acquisition in Different Types of Fertilizers and Fertilization Techniques}

The study results of [11] found decreased rhizosphere $\mathrm{pH}$ with the application of $\mathrm{N}$ as $\mathrm{NH}_{4}^{+}$ increased the availability of (bioavailability) P-organic to the soil. Rhizospheric acidification in connection with the application of $\mathrm{N}$ fertilizer as $\mathrm{NH}_{4}{ }^{+}$increases the movement and acquisition of inorganic $\mathrm{P}$ in the soils. In contrast, the soil $\mathrm{pH}$ increases with $\mathrm{NO}_{3}$ treatment. On the contrary to the research results of [1], in the rizobox experiment it showed greater biomass in all treatments with $\mathrm{NO}_{3}^{-}$. This showed that $T$. caerulenscens preferred $\mathrm{NO}_{3}{ }^{-}$compared to $\mathrm{NH}_{4}$. Results of [12] in the effect of $\mathrm{pH}$ on $\operatorname{root} \mathrm{N}$ acquisition showed that corn root releases more hydroxyl ions at $\mathrm{pH} 4$ and 5 at a constant $\mathrm{pH}$ compared to a non-constant $\mathrm{pH}$.

Ion acquisition can continue by the exchange of electrons which neutralize ions in the body of the plants [13, 14]. This can occur in the presence of hydrogen, bicarbonate or hydroxyl. Ions can be released if there is access to cation or anion acquisition. The $\mathrm{pH}$ of the solution outside the root will increase if more anions than the cation are absorbed, and decrease if more cations are absorbed $[15,16]$. For example, if $\mathrm{N}$ is absorbed as nitrate, the anion is absorbed, and the $\mathrm{pH}$ outside the root will increase, and if ammonium (NH4) is absorbed, the $\mathrm{pH}$ will decrease. Changes in $\mathrm{pH}$ in the rhizosphere also have important consequences for the acquisition of $\mathrm{P}$ [17-19], the acquisition of $\mathrm{Cd}$ and $\mathrm{Zn}$ in T. caerulescens [1], and the acquisition of $\mathrm{Cu}$ in tomato 
plants and oilseed rape on acid soils[20]. Localized fertilization in one area can affect the acquisition of plant nutrients, which is influenced by the plant's physiological adaptability. Adaptation of plants to higher acquisitions when nutrient distribution is not homogeneous or low availability is performed by changing root architecture, for example by increasing surface allocation and root length to the topsoil [2, 21].

\section{CONCLUSION}

This research provides current information that rattan roots cannot increase soil $\mathrm{pH}$ with the presence of $\mathrm{N}$-Urea and N-ZA fertilizer inputs. Even, soil $\mathrm{pH}$ was generally lower compared to the control, so that $\mathrm{N}$ fertilizer inputs cannot increase $\mathrm{N}$ acquisition and rattan seedling biomass.

\section{ACKNOWLEDGEMENTS}

Authors would like to thank Ministry of Research and Tecnology of the Republic of Indonesia and Directorate General of Research and Development Empowerment of the Republic of Indonesia, Tadulako University, and Alkhairaat University.

\section{REFERENCES}

1. Xie, H. L., Jiang, R. F., Zhang, F. S., McGrath, S. P., \& Zhao, F. J. (2009). Effect of nitrogen form on the rhizosphere dynamics and uptake of cadmium and zinc by the hyperaccumulator Thlaspi caerulescens. Plant and Soil, 318(1-2), 205-215. https://doi.org/10.1007/s11104-008-9830-y

2. Zhang, H., \& Forde, B. (2000). Complete genomic characterization of eggplant mottled dwarf virus from agapanthus sp. By deep sequencing and de novo assembly. Journal of Plant Pathology, 51, 5159. https://doi.org/10.4454/JPP.V96I3.003

3. Ahkami, A. H., Allen White, R., Handakumbura, P. P., \& Jansson, C. (2017). Rhizosphere engineering: Enhancing sustainable plant ecosystem productivity. Rhizosphere, 3(April), 233-243. https://doi.org/10.1016/j.rhisph.2017.04.012

4. Odelade, K. A., \& Babalola, O. O. (2019). Bacteria, fungi and archaea domains in rhizospheric soil and their effects in enhancing agricultural productivity. International Journal of Environmental Research and Public Health, 16(20). https://doi.org/10.3390/ijerph16203873

5. Belcher, B., Rujehan, Imang, N., \& Achadiawan, R. (2004). Rattan, Rubber, or Oil Palm, : Cultural and finacial Considerations for farmer in Kalimantan. Economic Botany, 58, S77-S87. https://doi.org/10.1663/0013-0001(2004)58

6. Meijaard, E., Achdiawan, R., Wan, M., \& Taber, A. (2014). The decline of a once-important nontimber forest product in Indonesia.

7. Sari, E. P. (2013). Formulation of Slow Release Nitrogen Fertilizer from Urea, Zeolite and Humic Acid and Its Effect on Corn Growth. Thesis, Bogor Agricultural University.
8. Dechat, T., Pfleghaar, K., Sengupta, K., Shimi, T., Shumaker, D. K., Solimando, L., \& Goldman, R. D. (2008). Nuclear lamins: Major factors in the structural organization and function of the nucleus and chromatin. Genes and Development, 22(7), 832-853. https://doi.org/10.1101/gad.1652708

9. Zhou, S., Xiang, Y., Tie, L., Han, B., \& Huang, C. (2018). Simulated nitrogen deposition significantly reduces soil respiration in an evergreen broadleaf forest in western China. PLoS ONE, 13(9), 1-15. https://doi.org/10.1371/journal.pone.0204661

10. Voisin, A. S., Salon, C., Munier-Jolain, N. G., \& Ney, B. (2002). Effect of mineral nitrogen on nitrogen nutrition and biomass partitioning between the shoot and roots of pea (Pisum sativum L.). Plant and Soil, 242(2), 251-262. https://doi.org/10.1023/A:1016214223900

11. Zhang, Y., Zhou, Z., \& Yang, Q. (2013). Genetic variations in root morphology and phosphorus efficiency of Pinus massoniana under heterogeneous and homogeneous low phosphorus conditions. Plant and Soil, 364(1-2), 93-104. https://doi.org/10.1007/s11104-012-1352-y

12. Masud, M. M., Guo, D., Li, J. yu, \& Xu, R. kou. (2014). Hydroxyl release by maize (Zea mays L.) roots under acidic conditions due to nitrate absorption and its potential to ameliorate an acidic Ultisol. Journal of Soils and Sediments, 14(5), 845-853. https://doi.org/10.1007/s11368-0130837-5

13. Serianni, G., Agostinetti, P., Agostini, M., Antoni, V., Aprile, D., Baltador, C., Zaupa, M. (2017). Neutralisation and transport of negative ion beams: Physics and diagnostics. New Journal of Physics, 19(4). https://doi.org/10.1088/1367-2630/aa64bd

14. Sharma, P., Jha, A. B., Dubey, R. S., \& Pessarakli, M. (2012). Reactive Oxygen Species, Oxidative Damage, and Antioxidative Defense Mechanism in Plants under Stressful Conditions. Journal of Botany, 2012, 1-26. https://doi.org/10.1155/2012/217037

15. Staunton, S., \& Leprince, F. (1996). Effect of $\mathrm{pH}$ and some organic anions on the solubility of soil phosphate: Implications for $\mathrm{P}$ bioavailability. European Journal of Soil Science, 47(2), 231-239. https://doi.org/10.1111/j.13652389.1996.tb01394.x

16. Yang, L. T., Qi, Y. P., Jiang, H. X., \& Chen, L. S. (2013). Roles of organic acid anion secretion in aluminium tolerance of higher plants. BioMed Research International, 2013, 9-15. https://doi.org/10.1155/2013/173682

17. Hinsinger, P., Betencourt, E., Bernard, L., Brauman, A., Plassard, C., Shen, J., Zhang, F. (2011). P for two, sharing a scarce resource: Soil phosphorus acquisition in the rhizosphere of intercropped species. Plant Physiology, 156(3), 1078-1086. https://doi.org/10.1104/pp.111.175331

18. Wang, X., \& Tang, C. (2018). The role of rhizosphere $\mathrm{pH}$ in regulating the rhizosphere 
priming effect and implications for the availability of soil-derived nitrogen to plants. Annals of Botany, 121(1), 143-151. https://doi.org/10.1093/aob/mcx138

19. Robles-Aguilar, A. A., Pang, J., Postma, J. A., Schrey, S. D., Lambers, H., \& Jablonowski, N. D. (2019). The effect of $\mathrm{pH}$ on morphological and physiological root traits of Lupinus angustifolius treated with struvite as a recycled phosphorus source. Plant and Soil, 434(1-2), 65-78. https://doi.org/10.1007/s11104-018-3787-2
20. Chaignon, V., Bedin, F., \& Hinsinger, P. (2002). Copper bioavailability and rhizosphere $\mathrm{pH}$ changes as affected by nitrogen supply for tomato and oilseed rape cropped on an acidic and a calcareous soil. Plant and Soil, 243(2), 219-228. https://doi.org/10.1023/A:1019942924985

21. Graciano, C., Tambussi, E. A., Castán, E., \& Guiamet, J. J. (2009). Dry mass partitioning and nitrogen uptake by Eucalyptus grandis plants in response to localized or mixed application of phosphorus. Plant and Soil, 319(1-2), 175-184. https://doi.org/10.1007/s11104-008-9859-y. 